\title{
Early Administration of Low-Dose Aspirin for the Prevention of Severe and Mild Preeclampsia: A Systematic Review and Meta-Analysis
}

\author{
Stéphanie Roberge, M.Sc. ${ }^{1}$ Yves Giguère, M.D., Ph.D. ${ }^{2}$ Pia Villa, M.D. ${ }^{3}$ Kypros Nicolaides, M.D. ${ }^{4}$ \\ Merja Vainio, M.D. ${ }^{5}$ Jean-Claude Forest, M.D., Ph.D. ${ }^{2}$ Peter von Dadelzen, M.B.Ch.B., D.Phil. ${ }^{6}$ \\ Daniel Vaiman, Ph.D. ${ }^{7}$ Sylvie Tapp, B.Sc. ${ }^{1}$ Emmanuel Bujold, M.D., M.Sc., F.R.C.S.C. ${ }^{8}$
}

\footnotetext{
${ }^{1}$ Department of Social and Preventive Medicine, Faculty of Medicine, Université Laval, Quebec, Canada

2 Department of Molecular Biology, Medical Biochemistry and Pathology, Faculty of Medicine, Université Laval, Quebec, Canada

${ }^{3}$ Department of Obstetrics and Gynecology, University of Helsinki and Helsinki University Central Hospital, Helsinki, Finland

${ }^{4}$ Harris Birthright Research Centre of Fetal Medicine, King's College Hospital, London, United Kingdom

${ }^{5}$ Kanta-Häme Central Hospital, Hämeenlinna, Finland

${ }^{6}$ Department of Obstetrics and Gynaecology, University of British Columbia, Vancouver, British Columbia, Canada

${ }^{7}$ Genomics and Epigenetics of Human Reproduction, Institut Cochin, Institut National de la Santé et de la Recherche Médicale (INSERM), and Université Paris Descartes, Paris, France

${ }^{8}$ Department of Obstetrics and Gynecology, Faculty of Medecine,

Université Laval, Quebec, Canada
}

\begin{abstract}
Address for correspondence and reprint requests Emmanuel Bujold, M.D., M.Sc., F.R.C.S.C., Associate Professor, Department of Obstetrics and Gynecology, Faculty of Medicine, Université Laval, 2705 Boulevard Laurier, Québec, QC G1V 4G2, Canada (e-mail: emmanuel.bujold@crchul.ulaval.ca).
\end{abstract}

Am J Perinatol 2012;29:551-556.

\begin{abstract}
Objective To determine whether early administration of aspirin prevents severe and mild preeclampsia.

Study Design A systematic review and meta-analysis of randomized controlled trials were performed. Studies in which women were randomized at or before 16 weeks' gestation to low-dose aspirin versus placebo or no treatment were included. The outcomes of interest were severe preeclampsia and mild preeclampsia. Pooled relative risks with their $95 \%$ confidence intervals (Cls) were calculated.

Keywords

- pregnancy

- preeclampsia

- aspirin

- systematic review

- meta-analysis

Results Among 7941 citations retrieved, 352 were completely reviewed and four studies (392 women) fulfilled the inclusion criteria and were analyzed. When compared with controls, aspirin started at $\leq 16$ weeks was associated with a significant reduction in severe (relative risk: $0.22,95 \% \mathrm{Cl}: 0.08$ to 0.57 ) but not mild (relative risk: $0.81,95 \% \mathrm{Cl}$ : 0.33 to 1.96$)$ preeclampsia.

Conclusion Low-dose aspirin initiated at or before 16 weeks reduces the risk of severe preeclampsia, but not mild preeclampsia.
\end{abstract}

Preeclampsia, which affects 2 to $8 \%$ of pregnancies, is a major cause of maternal and perinatal morbidity and mortality. ${ }^{1,2}$ It is usually defined as hypertension and proteinuria that occur at or after 20 weeks' gestation in women with previously normal blood pressure. The disease is considered to be severe when it is associated with liver damage, thrombocytopenia, received

November 25, 2011

accepted after revision

December 17, 2011

published online

April 11, 2012
Copyright ( $\odot 2012$ by Thieme Medical Publishers, Inc., 333 Seventh Avenue, New York, NY 10001, USA. Tel: +1(212) 584-4662.
DOI http://dx.doi.org/ 10.1055/s-0032-1310527. ISSN 0735-1631. 
fetal growth restriction (FGR), and symptoms such as headache, visual disturbance, and right upper-quadrant pain. ${ }^{3}$ However, published reports use differing criteria for the diagnoses of preeclampsia and severe preeclampsia. A growing body of evidence suggests that severe and mild preeclampsia develop from two distinct pathophysiological processes. Women with preterm preeclampsia are at higher risk of severe preeclampsia and eclampsia, and their adverse consequences. $^{4-7}$

Bujold et al found that low-dose aspirin initiated at or before 16 weeks' gestation could prevent $\sim 50 \%$ of preeclampsia and $55 \%$ of FGR. $^{8}$ It has been suggested that low-dose acetylsalicylic acid therapy inhibits thromboxane more than prostacyclin production and thereby protects against vasoconstriction and pathological blood coagulation in the placenta. ${ }^{9}$ The use of low-dose aspirin given in early pregnancy has been associated with improvement of uterine artery blood flow resistance, suggesting a greater remodeling of the spiral artery. ${ }^{10,11}$ Therefore, we hypothesized that lowdose aspirin could be more effective in the prevention of severe preeclampsia than in the prevention of mild disease. We performed a systematic review and meta-analysis of randomized controlled trials (RCTs) that evaluated the benefits of low-dose aspirin prophylaxis started before 16 weeks' gestation in the prevention of severe preeclampsia.

\section{Methods}

\section{Sources}

Keywords and MeSH terms "aspirin," “antiplatelet," "salicy*," "ASA," "pregnancy-complication," "hypertens*," "blood press*," “*eclamp*," "PIH," “toxaemi*," "IUGR” were combined for electronic databases search. Relevant citations were extracted from Embase, PubMed, the Cochrane Central Register of Controlled Trials (CENTRAL), and Web of Science from 1965 to October 2011. No language restriction was imposed. All articles were sorted by the first reviewer (S.R.) for more detailed evaluation. Citation and abstract were retrieved for the second sort and was reviewed by two reviewers (S.R., E. B.). All relevant trials were entirely reviewed by the same two reviewers. Other systematic reviews were used for additional search. ${ }^{12-14}$ Quality and integrity of this review were validated with PRISMA (preferred reporting items) for systematic reviews and meta-analyses. ${ }^{15}$

\section{Study Selection}

This meta-analysis includes only prospective, randomized, controlled trials. The population in the studies involved pregnant women at risk of preeclampsia treated with lowdose aspirin initiated at or before 16 weeks of gestation. No restrictions were applied to risk criteria for preeclampsia. Low-dose aspirin was defined as 50 to $150 \mathrm{mg}$ of acetylsalicylic acid daily, alone or in combination with $300 \mathrm{mg}$ of dipyridamole or less, another antiplatelet agent. The control group had to be allocated to placebo or no treatment. Studies' qualities were evaluated using Cochrane Handbook Criteria for judging risk of bias tool, and studies with high risk of bias were considered for exclusion. ${ }^{16}$

\section{Outcomes}

The primary outcome was the occurrence of severe or mild preeclampsia. The American College of Obstetricians and Gynecologist defines preeclampsia as blood pressure of $140 \mathrm{~mm}$ $\mathrm{Hg}$ systolic or higher or $90 \mathrm{~mm} \mathrm{Hg}$ diastolic or higher that occurs after 20 weeks of gestation in a woman with previously normal blood pressure plus proteinuria, defined as urinary excretion of $0.3 \mathrm{~g}$ protein or higher in a 24-hour urine specimen. ${ }^{17}$ Severe preeclampsia is diagnosed if, in addition to the above criteria, one or more of the following criteria is present: sustained (at least 6 hours) systolic blood pressure of at least $160 \mathrm{~mm} \mathrm{Hg}$, or sustained diastolic blood pressure of at least $110 \mathrm{~mm} \mathrm{Hg}$, severe proteinuria $5 \mathrm{~g}$ or higher protein in 24 hours, or $3+$ on dipstick), oliguria of less than $500 \mathrm{~mL}$ in 24 hours, cerebral or visual disturbances, pulmonary edema or cyanosis, epigastric or right upper-quadrant pain, impaired liver function, thrombocytopenia, FGR. ${ }^{17}$ However, as the definition of severe preeclampsia varies between countries; we accepted all definitions that we considered similar. When data regarding severe preeclampsia were not provided, we contacted the corresponding author or first author for additional information. When not specifically provided, the number of mild preeclampsia was calculated as the cases of all preeclampsia minus the cases of severe preeclampsia.

\section{Statistical Analysis}

Studies were combined and analyzed with Review Manager 5.0.25 (The Nordic Cochrane Centre, The Cochrane Collaboration, Copenhagen, Denmark) software. Individual risk ratios (RRs) were calculated for each study, and pooled for global analysis with 95\% confidence intervals (CIs). Analysis of preeclampsia was divided into severe preeclampsia and mild preeclampsia. Global RR was calculated according to DerSimonian and Laird random effect models in case of heterogeneity. ${ }^{18,19}$ Heterogeneity between studies was analyzed using the Higgins' $\mathrm{I}^{2} .{ }^{20}$ The distribution of trials was examined with funnel plots to assess publication bias. ${ }^{21}$

\section{Results}

The literature search identified 7941 potentially eligible studies, and 352 were reviewed (-Fig. 1). The inclusion criteria were met by 15 studies but only four were included (392 women) for the final analysis because information on severe and mild preeclampsia were available. In three studies, women randomized to the control received placebo, ${ }^{11,22,23}$ and in the fourth study, they received no treatment (-Table 1). ${ }^{24}$

Administration of aspirin initiated at or before 16 weeks' gestation was associated with a significant reduction in the risk of overall preeclampsia (RR: $0.52,95 \% \mathrm{CI}$ : 0.38 to 0.76 , $p<0.01$ ) and severe preeclampsia, but not mild preeclampsia ( $\mathbf{- T a b l e ~} \mathbf{2}$ and -Figs. $\mathbf{2}$ and $\mathbf{3}$ ). The eight studies that were not included in the meta-analysis because of unavailable data regarding severe/mild preeclampsia but where the overall rate of preeclampsia was reported demonstrated a similar effect of aspirin on preeclampsia (RR: $0.22,95 \%$ CI 0.10 to 0.46 , $p<0.01) .^{25-32}$ 


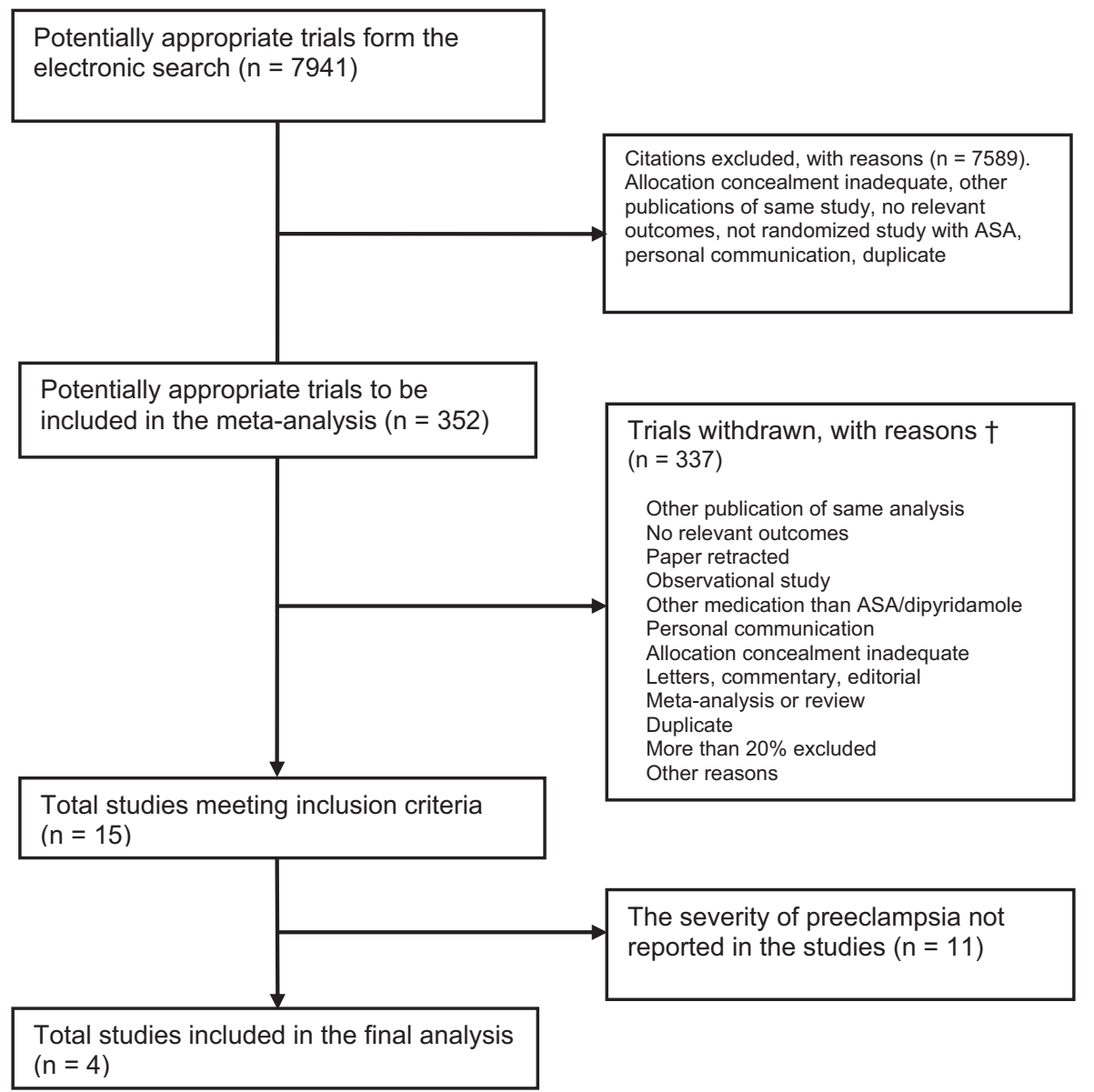

Figure 1 Flow diagram showing the selection process of articles. ASA, acetylsalicylic acid.

In the included studies, the homogeneity for the reduction in the relative risk of severe preeclampsia was high $\left(\mathrm{I}^{2}: 0 \%\right)$, whereas the homogeneity for the effect on the relative risk of mild preeclampsia was moderate $\left(\mathrm{I}^{2}: 49 \%\right)$. Random model was used for both outcomes because heterogeneity between studies including the same population was present for at least one outcome. Analysis of the funnel plot was precluded because of the small number of included studies. According to Cochrane Handbook Criteria for judging risk of bias tool, all studies were judged to have low or unclear risk of bias. ${ }^{16}$

\section{Discussion}

The results of this meta-analysis, which includes the results of one additional RCT to those provided in our previous report, ${ }^{8}$ is in complete agreement with the results of our previous report demonstrating a major beneficial effect of early onset, low-dose aspirin in halving the overall risk of preeclampsia, and this effect was particularly marked in the case of severe preeclampsia whose relative risk was reduced by $\sim 90 \%$. In contrast, the use of aspirin was not associated with a significant reduction in the relative risk of mild preeclampsia.

One likely explanation for a high effectiveness of early onset, low-dose aspirin in the prevention of severe preeclampsia but not of mild disease is that the pathophysiology of the two conditions is different and only the former is susceptible to the effects of aspirin. There is supportive evidence from Doppler ultrasound studies that in a high proportion of cases of severe preeclampsia with associated FGR, unlike cases of mild disease without FGR, impedance to flow in the uterine arteries is increased. ${ }^{33}$ Such increased impedance to flow is thought to be a consequence of inadequate trophoblastic invasion of the maternal spiral arteries and their conversion from narrow muscular vessels to wide nonmuscular channels. ${ }^{34}$

It is possible that early onset, low-dose aspirin improves placentation and, therefore, reduces the risk of severe preeclampsia. An alternative explanation for our findings is that in all cases of preeclampsia there is impaired placentation, but a spectrum of placental impairment is reflected in the severity of the clinical manifestations of the disease. In this case, the beneficial effect of aspirin on placentation could actually reduce substantially the risk of those cases that were destined to develop mild preeclampsia and convert the predestined severe to mild preeclamptic cases.

The main weaknesses of our study are the small number of studies included in the analysis and the heterogeneity in the 
554 Early Administration of Low-Dose Aspirin for Preeclampsia Roberge et al.

Table 1 Characteristics of Included Studies

\begin{tabular}{|c|c|c|c|c|c|c|}
\hline $\begin{array}{l}\text { First } \\
\text { Author, } \\
\text { Year }\end{array}$ & $\begin{array}{l}\text { Gestational } \\
\text { Age at } \\
\text { Initiation of } \\
\text { Treatment } \\
\text { (wk) }\end{array}$ & $\begin{array}{l}\text { Participants } \\
\text { (n) }\end{array}$ & Inclusion Criteria & Intervention & $\begin{array}{l}\text { Definition of } \\
\text { Preeclampsia }\end{array}$ & $\begin{array}{l}\text { Criteria for Severe } \\
\text { Preeclampsia }\end{array}$ \\
\hline $\begin{array}{l}\text { August, } \\
1994^{22}\end{array}$ & $13-15$ & 49 & $\begin{array}{l}\text { Chronic hypertension or } \\
\text { previous severe } \\
\text { preeclampsia }\end{array}$ & $\begin{array}{l}\text { ASA } 100 \mathrm{mg} \\
\text { vs placebo }\end{array}$ & $\begin{array}{l}\text { Rise of } 30 \mathrm{~mm} \mathrm{Hg} \\
\text { of SBP and } 15 \mathrm{~mm} \\
\mathrm{Hg} \text { of DBP with } \\
\text { proteinuria and } \\
\text { hyperuricemia or } \\
\text { HELLP syndrome }\end{array}$ & $\begin{array}{l}\text { Severe disease } \\
\text { necessitating } \\
\text { premature delivery }\end{array}$ \\
\hline $\begin{array}{l}\text { Ebrashy, } \\
2005^{24}\end{array}$ & $14-16$ & 136 & $\begin{array}{l}\text { Abnormal uterine } \\
\text { artery Doppler and risk } \\
\text { factors for preeclampsia } \\
\text { and intrauterine growth } \\
\text { restriction }\end{array}$ & $\begin{array}{l}\text { ASA } 75 \mathrm{mg} \\
\text { vs no } \\
\text { treatment }\end{array}$ & $\begin{array}{l}S B P \geq 140 \text { and DBP } \\
\geq 90 \mathrm{~mm} \mathrm{Hg} \text { with } \\
\text { proteinuria } \\
>300 \mathrm{mg} / \mathrm{d}\end{array}$ & $\begin{array}{l}\text { SBP reached } \\
160 \mathrm{~mm} \mathrm{Hg}, \mathrm{DBP} \\
\text { reached } 110 \mathrm{~mm} \\
\mathrm{Hg} \text {, proteinuria } \\
\text { reached } 2 \mathrm{~g} \text { in } 24-\mathrm{h} \\
\text { urine sample, urine } \\
\text { output was } \\
<500 \mathrm{~mL} / \mathrm{d} \text {, } \\
\text { platelet count was } \\
<100,000 \text { per } \\
\mathrm{mm}^{3} \text {, and liver } \\
\text { enzymes were } \\
\text { increased }\end{array}$ \\
\hline $\begin{array}{l}\text { Vainio, } \\
2002^{11}\end{array}$ & $12-14$ & 86 & $\begin{array}{l}\text { Anamnestic risk factor } \\
\text { with abnormal uterine } \\
\text { Doppler }\end{array}$ & $\begin{array}{l}\text { ASA } 0.5 \mathrm{mg} / \\
\mathrm{kg} / \mathrm{d} \text { vs } \\
\text { placebo }\end{array}$ & $\begin{array}{l}S B P \geq 140 \text { and } D B P \\
\geq 90 \mathrm{~mm} \mathrm{Hg} \text { with } \\
\text { proteinuria } \\
\geq 300 \mathrm{mg} / \mathrm{d}\end{array}$ & $\begin{array}{l}\text { Birth weight }<10 \text { th } \\
\text { percentile }\end{array}$ \\
\hline $\begin{array}{l}\text { Villa, } \\
2010^{23}\end{array}$ & $13-14$ & 121 & $\begin{array}{l}\text { Anamnestic risk factor } \\
\text { with abnormal uterine } \\
\text { Doppler (bilateral } \\
\text { second-degree uterine } \\
\text { artery notch) }\end{array}$ & $\begin{array}{l}\text { ASA } 100 \mathrm{mg} \\
\text { vs placebo }\end{array}$ & $\begin{array}{l}\mathrm{BP} \geq 140 / 90 \text { in } \\
\text { consecutive } \\
\text { measurements and } \\
\text { proteinuria } \geq 0.3 \mathrm{~g} / \\
24 \mathrm{~h}\end{array}$ & $\begin{array}{l}\mathrm{BP} \geq 160 \text { systolic } \\
\text { and/or } \geq 110 \\
\text { diastolic and/or } \\
\text { proteinuria } \geq 5 \mathrm{~g} / \\
24 \mathrm{~h}\end{array}$ \\
\hline
\end{tabular}

ASA, acetylsalicylic acid; BP, blood pressure; DBP, diastolic blood pressure; HELLP syndrome, hemolysis, elevated liver enzymes, and low platelet count; SBP, systolic blood pressure.

definition of severe preeclampsia. Because most of the studies potentially eligible were completed before 2000 , the primary data are no longer available for accurate classification of severity. This is especially true as current definitions of severe preeclampsia perform poorly in identifying true incremental risk of either adverse maternal or adverse perinatal outcomes. ${ }^{35}$ However, the diagnosis of preeclampsia remains more reliable when combined with severity criteria, and this could be another reason for our findings because the diagnosis of mild preeclampsia can be considered more subjective.

Our meta-analysis is also limited by the absence of very large trials. The six largest trials that evaluated the impact of low-dose aspirin in preeclampsia recruited women after 16 weeks' gestation. ${ }^{36-41}$ The absence of studies showing no beneficial effects in the funnel plot suggests the possibility of publication bias. Moreover, the small number of studies that reported the prevalence of severe preeclampsia and/or preterm preeclampsia precludes the interpretation of funnel plots for those outcomes. However, the great homogeneity of the results between the studies included in our meta-analysis for severe preeclampsia suggests a good validity of our findings. Two eligible studies were excluded because they did not report the cases of mild preeclampsia, preventing the comparison between severe and mild disease. ${ }^{26,27}$ However,

Table 2 Relative Risk of Severe Preeclampsia and Mild Preeclampsia Associated with the Use of Low-Dose Aspirin at or Before 16 Weeks' Gestation

\begin{tabular}{|l|l|l|l|l|l|}
\hline \multirow{2}{*}{ Outcomes } & \multicolumn{2}{|l|}{$\begin{array}{l}\text { Prevalence of the } \\
\text { Outcomes (\%) }\end{array}$} & \multirow{2}{*}{ Relative Risk (95\% Confidence Intervals) } & \multirow{2}{*}{$\boldsymbol{p}$ Value } & $\mathbf{I}^{\mathbf{2}}$ \\
\cline { 2 - 5 } & Aspirin & Controls & & $0.22(0.08,0.57)$ & $<0.001$ \\
\hline Severe preeclampsia & 2.0 & 12.6 & $0.81(0.33,1.96)$ & 0.63 \\
\hline Mild preeclampsia & 16.9 & 22.0 & $49 \%$ \\
\hline
\end{tabular}




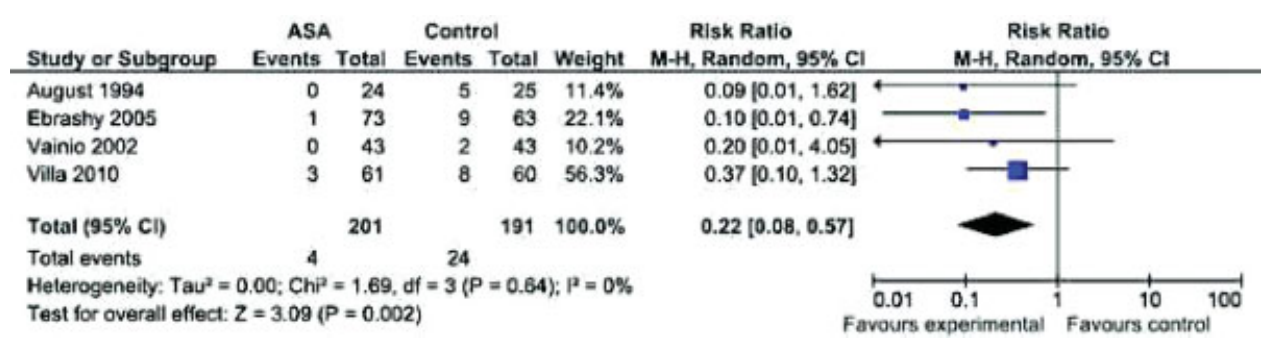

Figure 2 Forest plot of the effect of low-dose aspirin initiated at or before 16 weeks' gestation on the prevalence of severe preeclampsia. ASA, acetylsalicylic acid; $\mathrm{Cl}$, confidence interval; DPI, dots per inch; $\mathrm{M}-\mathrm{H}$, Mantel-Haenszel.

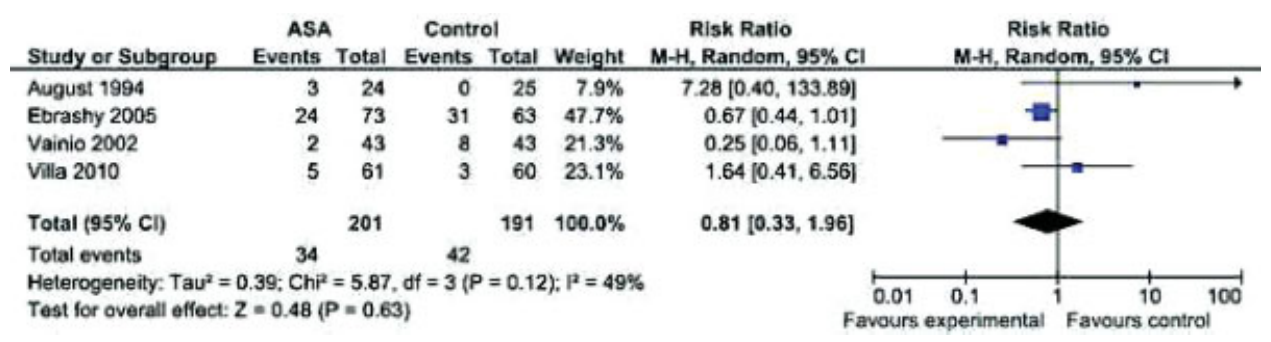

Figure 3 Forest plot of the effect of low-dose aspirin initiated at or before 16 weeks' gestation on the prevalence of mild preeclampsia. ASA, acetylsalicylic acid; $\mathrm{Cl}$, confidence interval; DPI, dots per inch; M-H, Mantel-Haenszel.

adding those studies to the analysis would have only strengthened the association of low-dose aspirin and risk reduction of severe preeclampsia (six studies, RR: $0.18,95 \%$ CI: 0.08 to 0.41 ). These two studies were included in the eight studies that did not differentiate between mild and severe preeclampsia and therefore could explain the important effect of aspirin found in that subgroup.

Our meta-analysis included studies that recruited women at high risk for preeclampsia using a wide variety of inclusion criteria, and the majority of the women had a previous history of preeclampsia. We believe that definitive trials are required to determine whether low-dose aspirin can prevent the adverse maternal and perinatal consequences of severe preeclampsia in high-risk women who may be identified through predictive screening programs. ${ }^{42-45}$ Such trials should consider evaluating the role of aspirin resistance combined, or not, with adjustment of aspirin dosage. ${ }^{42,46-48}$ Based on the current study, such large-scale trials should aim to decrease the risk of the adverse maternal and perinatal outcomes associated with severe rather than mild preeclampsia.

In conclusion, our meta-analysis confirms that low-dose aspirin initiated between 7 and 16 weeks' gestation is associated with a significant reduction in severe preeclampsia, in a population of women identified at high risk for preeclampsia.

\section{References}

1 World Health Organization International Collaborative Study of Hypertensive Disorders of Pregnancy. Geographic variation in the incidence of hypertension in pregnancy. Am J Obstet Gynecol 1988;158:80-83
2 Duley L. The global impact of pre-eclampsia and eclampsia. Semin Perinatol 2009;33:130-137

3 Magee LA, Helewa M, Moutquin JM, von Dadelszen P; Hypertension Guideline Committee; Strategic Training Initiative in Research in the Reproductive Health Sciences (STIRRHS) Scholars. Diagnosis, evaluation, and management of the hypertensive disorders of pregnancy. J Obstet Gynaecol Can 2008;30(3, Suppl):S1-S48

4 Moldenhauer JS, Stanek J, Warshak C, Khoury J, Sibai B. The frequency and severity of placental findings in women with preeclampsia are gestational age dependent. Am J Obstet Gynecol 2003;189:1173-1177

5 Odegård RA, Vatten LJ, Nilsen ST, Salvesen KA, Austgulen R. Preeclampsia and fetal growth. Obstet Gynecol 2000;96:950-955

6 von Dadelszen P, Payne B, Li J, et al; PIERS Study Group. Prediction of adverse maternal outcomes in pre-eclampsia: development and validation of the fullPIERS model. Lancet 2011;377:219-227

7 MacKay AP, Berg CJ, Atrash HK. Pregnancy-related mortality from preeclampsia and eclampsia. Obstet Gynecol 2001;97:533-538

8 Bujold E, Roberge S, Lacasse Y, et al. Prevention of preeclampsia and intrauterine growth restriction with aspirin started in early pregnancy: a meta-analysis. Obstet Gynecol 2010;116(2 Pt 1):402-414

9 Schiff E, Peleg E, Goldenberg M, et al. The use of aspirin to prevent pregnancy-induced hypertension and lower the ratio of thromboxane A2 to prostacyclin in relatively high risk pregnancies. $\mathrm{N}$ Engl J Med 1989;321:351-356

10 Haapsamo M, Martikainen H, Räsänen J. Low-dose aspirin reduces uteroplacental vascular impedance in early and mid gestation in IVF and ICSI patients: a randomized, placebo-controlled doubleblind study. Ultrasound Obstet Gynecol 2008;32:687-693

11 Vainio M, Kujansuu E, Iso-Mustajärvi M, Mäenpää J. Low dose acetylsalicylic acid in prevention of pregnancy-induced hypertension and intrauterine growth retardation in women with bilateral uterine artery notches. BJOG 2002;109:161-167 
12 Askie LM, Duley L, Henderson-Smart DJ, Stewart LA; PARIS Collaborative Group. Antiplatelet agents for prevention of preeclampsia: a meta-analysis of individual patient data. Lancet 2007;369:1791-1798

13 Duley L, Henderson-Smart DJ, Meher S, King JF. Antiplatelet agents for preventing pre-eclampsia and its complications. Cochrane Database Syst Rev 2007(2):CD004659

14 Coomarasamy A, Honest H, Papaioannou S, Gee H, Khan KS. Aspirin for prevention of preeclampsia in women with historical risk factors: a systematic review. Obstet Gynecol 2003;101: 1319-1332

15 Moher D, Liberati A, Tetzlaff J, Altman DG; PRISMA Group. Preferred reporting items for systematic reviews and meta-analyses: the PRISMA statement. PLoS Med 2009;6:e1000097

16 Higgins JPT, Green S (eds.). Cochrane Handbook for Systematic Reviews of Interventions Version 5.1.0 [updated March 2011]. The Cochrane Collaboration, 2011. Available at: www.cochrane-handbook.org

17 ACOG Committee on Obstetric Practice; American College of Obstetricians and Gynecologists. ACOG practice bulletin. Diagnosis and management of preeclampsia and eclampsia. Number 33, January 2002. Int J Gynaecol Obstet 2002;77:67-75

18 DerSimonian R, Laird N. Meta-analysis in clinical trials. Control Clin Trials 1986;7:177-188

19 Chevalier P, van Driel M, Vermeire E. Hétérogénité dans les synthèses méthodiques et méta-analyses. Minerva 2007;6:160

20 Higgins JP, Thompson SG, Deeks JJ, Altman DG. Measuring inconsistency in meta-analyses. BMJ 2003;327:557-560

21 Egger M, Davey Smith G, Schneider M, Minder C. Bias in meta-analysis detected by a simple, graphical test. BMJ 1997; 315:629-634

22 August P, Helseth G, Edersheim TG, Hutson JM, Druzin M. Sustained relase, low-dose aspirin ameliorates but does not prevent preeclampsia (PE) in a high risk population. Proceedings of 9th International Congress, International Society for the Study of Hypertension. Sydney, Australia: Hypertension in Pregnancy; 1994:72.

23 Villa P, Taipale P, Räikkönen K, et al. PREDO trial-acetylsalicylic acid in preventing pre-eclampsia in high-risk women. 17th ISSHP World Congress at Melbourne, Australia in October 2010, Pregnancy Hypertension: 2010:S1-S41

24 Ebrashy A, Ibrahim M, Marzook A, Yousef D. Usefulness of aspirin therapy in high-risk pregnant women with abnormal uterine artery Doppler ultrasound at 14-16 weeks pregnancy: randomized controlled clinical trial. Croat Med J 2005;46:826-831

25 Azar R, Turpin D. Effect of Antiplatelet Therapy in Women at High Risk for Pregnancy-Induced Hypertension. Perugia, Italy: Proceedings of 7th World Congress of Hypertension in Pregnancy; 1990:257

26 Bakhti A, Vaiman D. Prevention of gravidic endothelial hypertension by aspirin treatment administered from the 8th week of gestation. Hypertens Res 2011;34:1116-1120

27 Beaufils M, Uzan S, Donsimoni R, Colau JC. Prevention of preeclampsia by early antiplatelet therapy. Lancet 1985;1:840-842

28 Benigni A, Gregorini G, Frusca T, et al. Effect of low-dose aspirin on fetal and maternal generation of thromboxane by platelets in women at risk for pregnancy-induced hypertension. N Engl J Med 1989;321:357-362

29 Hermida RC, Ayala DE, Iglesias M, et al. Time-dependent effects of low-dose aspirin administration on blood pressure in pregnant women. Hypertension 1997;30(3 Pt 2):589-595

30 Mesdaghinia E, Talari H, Zolfagharpour A, Abedzadeh M, Rezapourian P; Focused Conference Group. P15-Endothelium in health and disease aspirin may prevent preeclampsia and its complications in women with abnormal uterine artery Doppler ultrasound. Basic Clin Pharmacol Toxicol 2010;107:453

31 Michael C, Walters B. Low-dose aspirin in the prevention of preeclampsia: current evaluation. In: Teoh ESR, Macnaughton MC, eds. Maternal physiology and pathology. The current status of gynaecology and obstetrics serie. Carnforth, England: Parthenon; 1992:183-189

32 Tulppala M, Marttunen M, Söderstrom-Anttila V, et al. Low-dose aspirin in prevention of miscarriage in women with unexplained or autoimmune related recurrent miscarriage: effect on prostacyclin and thromboxane A2 production. Hum Reprod 1997;12:15671572

33 Yu CK, Khouri O, Onwudiwe N, Spiliopoulos Y, Nicolaides KH; Fetal Medicine Foundation Second-Trimester Screening Group. Prediction of pre-eclampsia by uterine artery Doppler imaging: relationship to gestational age at delivery and small-for-gestational age. Ultrasound Obstet Gynecol 2008;31:310-313

34 Pijnenborg R, Anthony J, Davey DA, et al. Placental bed spiral arteries in the hypertensive disorders of pregnancy. Br J Obstet Gynaecol 1991;98:648-655

35 Menzies J, Magee LA, Macnab YC, et al. Current CHS and NHBPEP criteria for severe preeclampsia do not uniformly predict adverse maternal or perinatal outcomes. Hypertens Pregnancy 2007;26: 447-462

36 CLASP (Collaborative Low-dose Aspirin Study in Pregnancy) Collaborative Group. CLASP: a randomised trial of low-dose aspirin for the prevention and treatment of pre-eclampsia among 9364 pregnant women. Lancet 1994;343:619-629

37 Caritis S, Sibai B, Hauth J, et al; National Institute of Child Health and Human Development Network of Maternal-Fetal Medicine Units. Low-dose aspirin to prevent preeclampsia in women at high risk. N Engl J Med 1998;338:701-705

38 ECPPA. ECPPA: randomised trial of low dose aspirin for the prevention of maternal and fetal complications in high risk pregnant women. ECPPA (Estudo Colaborativo para Prevenção da Pré-eclampsia com Aspirina) Collaborative Group. Br J Obstet Gynaecol 1996;103:39-47

39 Golding J; The Jamaica Low Dose Aspirin Study Group. A randomised trial of low dose aspirin for primiparae in pregnancy. $\mathrm{Br} J$ Obstet Gynaecol 1998;105:293-299

40 Rotchell YE, Cruickshank JK, Gay MP, et al. Barbados Low Dose Aspirin Study in Pregnancy (BLASP): a randomised trial for the prevention of pre-eclampsia and its complications. Br J Obstet Gynaecol 1998;105:286-292

41 Hauth JC, Goldenberg RL, Parker CR Jr, et al. Low-dose aspirin therapy to prevent preeclampsia. Am J Obstet Gynecol 1993;168:1083-1091; discussion 1091-1093

42 Bujold E, Tapp S, Audibert F, et al. Prevention of adverse pregnancy outcomes with low-dose ASA in early pregnancy: new perspectives for future randomized trials. J Obstet Gynaecol Can 2011;33: 480-483

43 Poon LC, Stratieva V, Piras S, Piri S, Nicolaides KH. Hypertensive disorders in pregnancy: combined screening by uterine artery Doppler, blood pressure and serum PAPP-A at 11-13 weeks. Prenat Diagn 2010;30:216-223

44 Giguère $Y$, Charland $M$, Bujold E, et al. Combining biochemical and ultrasonographic markers in predicting preeclampsia: a systematic review. Clin Chem 2010;56:361-375

45 Akolekar R, Syngelaki A, Sarquis R, Zvanca M, Nicolaides KH. Prediction of early, intermediate and late pre-eclampsia from maternal factors, biophysical and biochemical markers at 11-13 weeks. Prenat Diagn 2011;31:66-74

46 Dumont A, Flahault A, Beaufils M, Verdy E, Uzan S. Effect of aspirin in pregnant women is dependent on increase in bleeding time. Am J Obstet Gynecol 1999;180(1 Pt 1):135-140

47 Rey E, Rivard GE. Is testing for aspirin response worthwhile in high-risk pregnancy? Eur J Obstet Gynecol Reprod Biol 2011; 157:38-42

48 Wójtowicz A, Undas A, Huras $\mathrm{H}$, et al. Aspirin resistance may be associated with adverse pregnancy outcomes. Neuroendocrinol Lett 2011;32:334-339 